\title{
Antimicrobial Agents and Intestinal Microflora
}

\author{
Rintaro Nakaya, Toshio Chida, and Harumi Shibaoka \\ Department of Microbiology, Tokyo Medical and Dental University School \\ of Medicine, Yushima, Bunkyo-ku, Tokyo 113
}

(Received 15 October, 1981)

\begin{abstract}
The results of the studies described in this communication indicate that antimicrobials cause suppression of normal aerobic and anaerobic flora in a variety of ways. In conclusion, it is summarized that: (i) Changes in the intestinal microflora are the reflection of the antibacterial spectrum and activity specific to the antibiotic administered. (ii) Degrees of alteration in the flora correlate well to concentrations of drug in the intestinal contents, and particularly, with the antibiotics of parenteral administration, they depend on the concentrations excreted in the bile. (iii) Changes in the flora take place within $24 \mathrm{hr}$ of drug administration, and at least 2 weeks and usually 3 to 4 weeks are required for recovery of flora to normal levels. (iv) When bacteria that harbor $\mathrm{R}$ plasmids mediating resistance to the antibiotic used exist in the flora, the drug is inactivated, resulting in selective overgrowth of the resistant organisms. After withdrawal of the drug the resistant organisms may disappear or decrease in number. (v) Bifidobacteria are generally very sensitive to most of the antibiotics tested. (vi) Overgrowth of yeasts is seen during the course of drug administration. (vii) No adverse consequences ascribable to the direct effects of changes in the flora are observed.
\end{abstract}

Key words: Antimicrobial agents; intestinal flora; cephalosporins; penicillins; pipemidic acid; DJ-6783; Panfuran S; clioquinol

It is my great honor and privilege, as the first speaker in this Symposium, to present the studies of myself and my colleagues. In this paper we will discuss studies on the mode of changes in the intestinal microflora of man and experimental animals upon administration of a variety of antimicrobial agents-in particular, citing studies carried out during recent years in our laboratories.

Many reports have been made on the disturbances in the normal distribution and balance of intestinal bacteria after oral or parenteral administration of antimicrobial agents used for systemic infection therapy. In the earlier studies, only coliform bacteria were used as indicator organisms to follow up such disturbances in the flora. It has, however, become a recent trend to study the alteration in both aerobic and anaerobic bacteria $(2,6-9)$.

A variety of aims are possible for studies on the alteration of the intestinal flora resulting from administration of antimicrobial agents.

(i) Determination of quantitative and qualitative changes in the bacterial groups of the flora.

(ii) Determination of period of time of alteration and recovery of the flora to normal.

(iii) Investigation of emergence and colonization of antibiotic-resistant bacteria.

(iv) Investigation of adverse reactions of the host due to the alteration in the flora.

(v) Determination of the effects on the metabolism of bile acids and the absorp- 
Table 1. Subjects, routes, and dosages for administration of antimicrobial agents studied

\begin{tabular}{|c|c|}
\hline Antimicrobial agent & Subjects, routes, ${ }^{a}$ and dosages \\
\hline \multirow[t]{2}{*}{ Cefazolin (CEZ) } & Beagles; iv; $80 \mathrm{mg} / \mathrm{kg} /$ day, 2 wk \\
\hline & Beagles; iv; $200 \mathrm{mg} / \mathrm{kg} /$ day, $1 \mathrm{mo}$ \\
\hline Cefoxitin (CFX) & Beagles; iv; 80 and $400 \mathrm{mg} / \mathrm{kg} /$ day, 2 wk \\
\hline \multirow[t]{3}{*}{ Cefoperazone (CPZ) } & Human volunteers; iv; $2 \mathrm{~g} /$ day, 5.5 days \\
\hline & Beagles; im; 125, 250, and $500 \mathrm{mg} / \mathrm{kg} /$ day, $2 \mathrm{mo}$ \\
\hline & Beagles; iv; 100,200 , and $400 \mathrm{mg} / \mathrm{kg} / \mathrm{day}, 1 \mathrm{mo}$ \\
\hline \multirow[t]{2}{*}{ SM-1652 } & Human volunteers; iv; $1 \mathrm{~g} /$ day, 6 days \\
\hline & Cynomolgus monkeys; iv; $0.6 \mathrm{~g} / \mathrm{kg} /$ day, 12 and $24 \mathrm{wk}$ \\
\hline \multirow[t]{2}{*}{ Ampicillin (ABPC) } & Beagles; im; $1 \mathrm{~g} / \mathrm{kg} /$ day, $1 \mathrm{mo}$ \\
\hline & Rabbits; iv; 50 and $500 \mathrm{mg} / \mathrm{kg} /$ day, 15 days \\
\hline \multirow[t]{2}{*}{ Piperacillin (PIPC) } & Beagles; im; 0.25 and $1 \mathrm{~g} / \mathrm{kg} /$ day, $1 \mathrm{mo}$ \\
\hline & Rabbits; iv; 50 and $500 \mathrm{mg} / \mathrm{kg} /$ day, 15 days \\
\hline Pipemidic acid (PPA) & Beagles; po; $40 \mathrm{mg} / \mathrm{kg} /$ day, $1 \mathrm{wk}$ \\
\hline DJ-6783 & Beagles; po; $40 \mathrm{mg} / \mathrm{kg} /$ day, $1 \mathrm{wk}$ \\
\hline Panfuran S (PFS) & Patients; po; $1-2 \mathrm{~g} /$ day, 3 days \\
\hline Clioquinol (Cli) & SMON patients; po \\
\hline
\end{tabular}

tion of substances produced in the colon. (vi) Determination of the effects on the host's mechanisms of defense against infection.

The purpose of this report is to present a summarized review of our studies on the effects of antimicrobial agents on the aerobic and anaerobic flora in human and animal feces as listed in Table 1. The experimental methods used in these studies are those exclusively established by Mitsuoka et al. (4).

\section{Gephalosporins}

Cefazolin (CEZ): Two beagle dogs were intravenously injected with $200 \mathrm{mg}$ of CEZ per $\mathrm{kg}$ of body weight per day for 30 days (CEZ-200 group). Two dogs that were not given the drug served as controls. Stool specimens from these animals were analysed for both aerobic and anaerobic bacteria. The effects of CEZ treatment on the total flora and individual bacterial groups are shown in Fig. 1. A 2.5-fold decrease in total flora was observed in the CEZ-200 group compared with the control group. This modest difference is accounted for by the elimination of Eubacteria and Peptococcaceae and the dramatic suppression of Bacteroides, Bifidobacteria and Lactobacilli

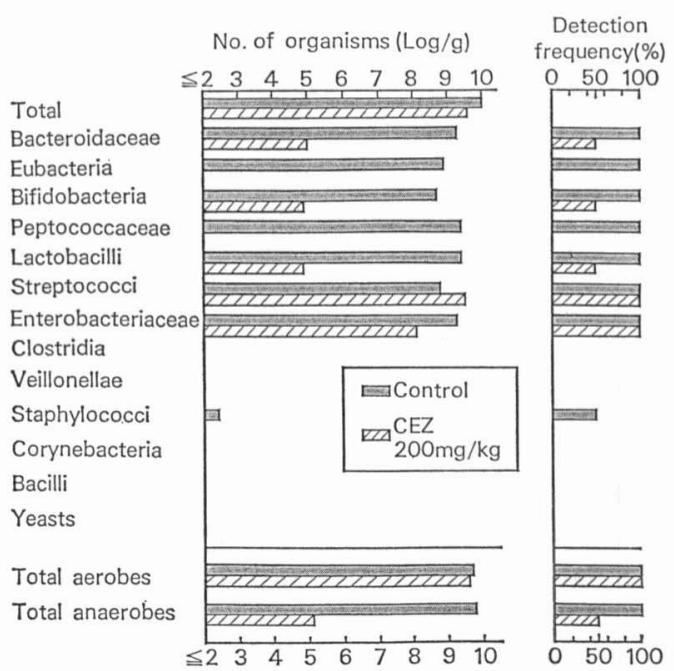

Fig. 1. Effect of cefazolin on the fecal microflora of beagle dogs after intravenous injections of $200 \mathrm{mg} / \mathrm{kg} /$ day for 1 month.

in the CEZ-200 group. In contrast, Streptococci showed a 5-fold increase, while Enterobacteriaceae decreased 16-fold. When total flora is divided into aerobes and anaerobes, the significant difference seen was a $10^{-4.7}$ decrease in total anaerobic organisms in the CEZ-200 group. With respect to detection frequency, there was a consistent tendency for loss of anaerobic bacteria in the CEZ-200 group.

Cefazolin and cefoxitin (CFX): Twelve 
beagle dogs were divided equally into 4 groups. One group received no antibiotic agent, another group received $80 \mathrm{mg}$ of CEZ per kg per day (CEX-80 group), and the third and fourth groups were given 80 and $400 \mathrm{mg}$ of CFX per $\mathrm{kg}$ per day, respectively (CFX-80 and CFX-400 groups). The drugs were intravenously injected into the animals for 14 days. The effects of CEZ and CFX on the intestinal flora were observed by examination of the stool specimens obtained on the day before the treatment had begun (day 0 of study), on days 2,8 , and 15 of study during the treatment period, and on days 22, 29, 36, and 43 of study in the period the drugs were withdrawn. Figure 2 shows the time sequence changes in the mean log counts of total flora and each bacterial group in the CEZ-80 group. (R. Nakaya, T. Chida, H. Shibaoka, N. Okamura, S. Horiuchi, N. Goto, T. Inoue, H. Une, Y. Osada and H. Ogawa, Jpn. J. Bacteriol. 35: 321, 1980). Most of the aerobes (the right-hand panel of Fig. 2) and the anaerobes (the left-hand panel of Fig. 2) were strikingly decreased or eliminated one day after the administration began (day 2 of study), except for Streptococci which were reduced only slightly in number $(1 / 16$ of the count on day 0 of study). The suppression of flora was seen to continue during the treatment period, although a sign of recovery of the flora to normal was observed at the end of treatment (day 15 of study). In particular, bacteria belonging to the Enterobacteriaceae group increased to the level existing prior to treatment. After withdrawal of CEZ, counts of most of the bacterial groups gradually increased to normal within 3 weeks and almost complete recovery was seen 4 weeks after the end of drug administration.

Similar alterations in fecal flora were observed in the CFX-80 and CFX-400 groups. Time sequence changes in the mean log counts of flora in the GFX-400 group are shown in Fig. 3. On day 2 of study all of the anaerobes were eliminated, while Streptococci showed a 126-fold de-

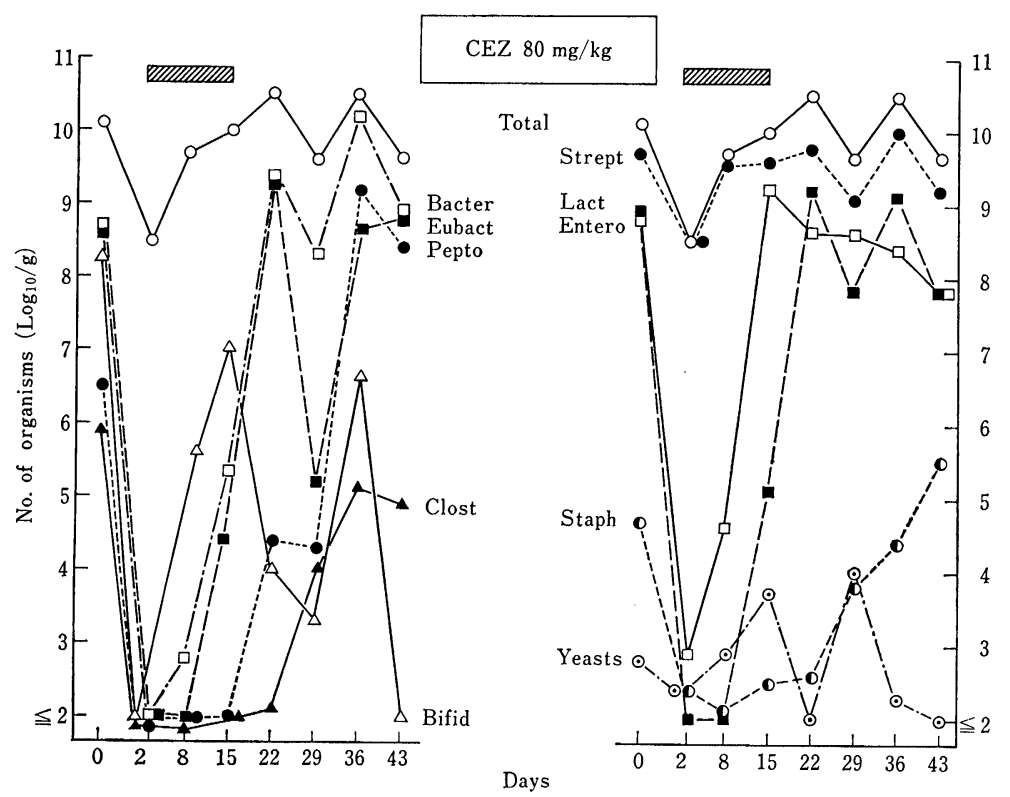

Fig. 2. Effect of cefazolin on the fecal microflora of beagle dogs. Intravenous injections of $80 \mathrm{mg} /$ $\mathrm{kg} /$ day for 14 days. 


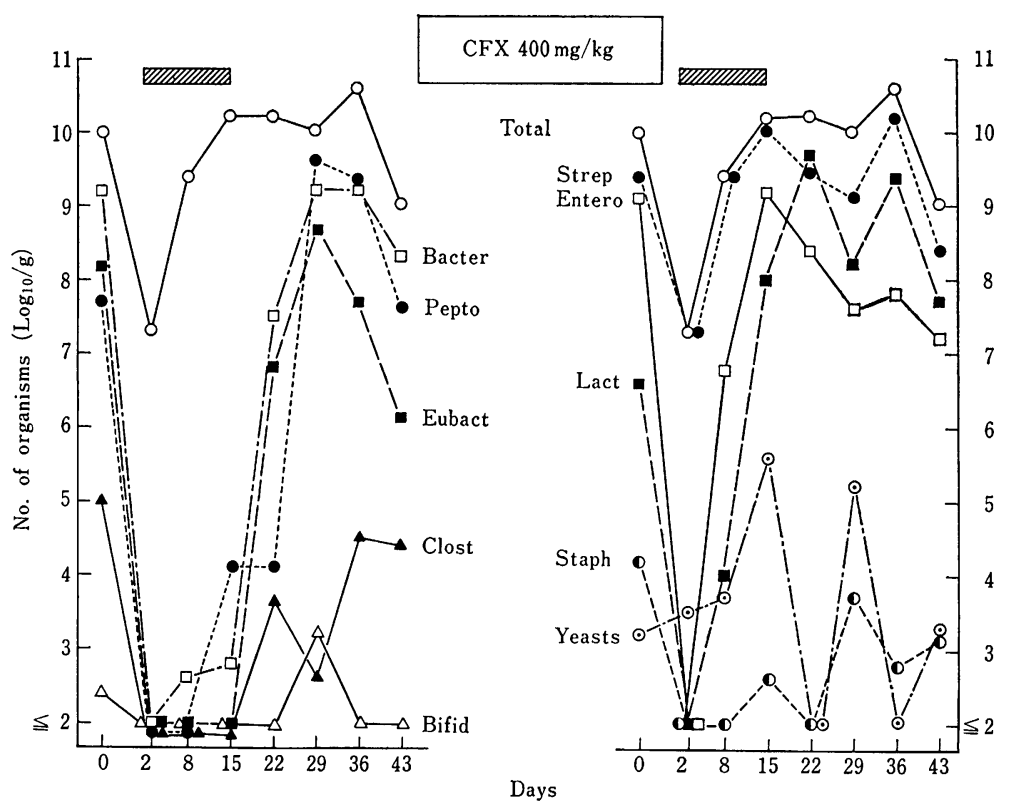

Fig. 3. Effect of cefoxitin on the fecal microflora of beagle dogs. Intravenous injections of $400 \mathrm{mg} /$ $\mathrm{kg} /$ day for 14 days.

crease which represented the total flora. Bacteria belonging to the Enterobacteriaceae and Lactobacillus groups, and yeasts as well as Streptococci tended to increase during the treatment period, whereas other bacterial groups were suppressed until a week after the withdrawal of CFX.

The amounts of CEZ and CFX excreted into the bile of beagle dogs were monitored (data not shown). By $8 \mathrm{hr}$ after intravenous injection, $4.1 \%$ of CEZ was recovered in the CEZ-80 group, whereas $1.0 \%$ of CFX was recovered in the CFX-400 group. These results well account for the suppression of flora in the stool specimens obtained one day after drug administration. The degrees of suppression of flora observed in the two groups were almost identical. It is indicated that this is due to the presence of comparable concentrations of both drugs in the intestinal contents of the animals used.

$S M-1652$, a new cephalosporin: The subjects studied were healthy adult male human volunteers (subjects No. 16, 17, and 18). Fecal specimens were collected prior to administration of the drug (day 0 of study) and on days 2, 4, and 7 of study into the treatment period, and at 1 and 2 weeks after the end of treatment. All three subjects received intravenously a single dose of $1 \mathrm{~g}$ of SM-1652 (Sumitomo Chemical Co., Osaka, and Yamanouchi Pharmaceutical Co., Tokyo) per day for 6 days. Stool specimens were analysed for aerobic and anaerobic bacteria. Fecal levels of the drug were also determined for all three subjects during the treatment period ( $R$. Nakaya, T. Chida, H. Shibaoka, and H. Sagara, Jpn. J. Bacteriol. 36: 370, 1981; Manuscripts submitted to Chemotherapy).

SM-1652 caused drastic suppression of normal aerobic and anaerobic flora in subjects No. 16 and 17 on days 3 and 2 of study after the administration of the drug, respectively, and most of the organisms were eliminated within the treatment period. Typical changes observed in subject No. 17 are shown in the upper panels of Fig. 4. The changes in flora in subject No. 17 were similar to, but more striking than, those in the beagle dogs treated with CEZ and CFX 

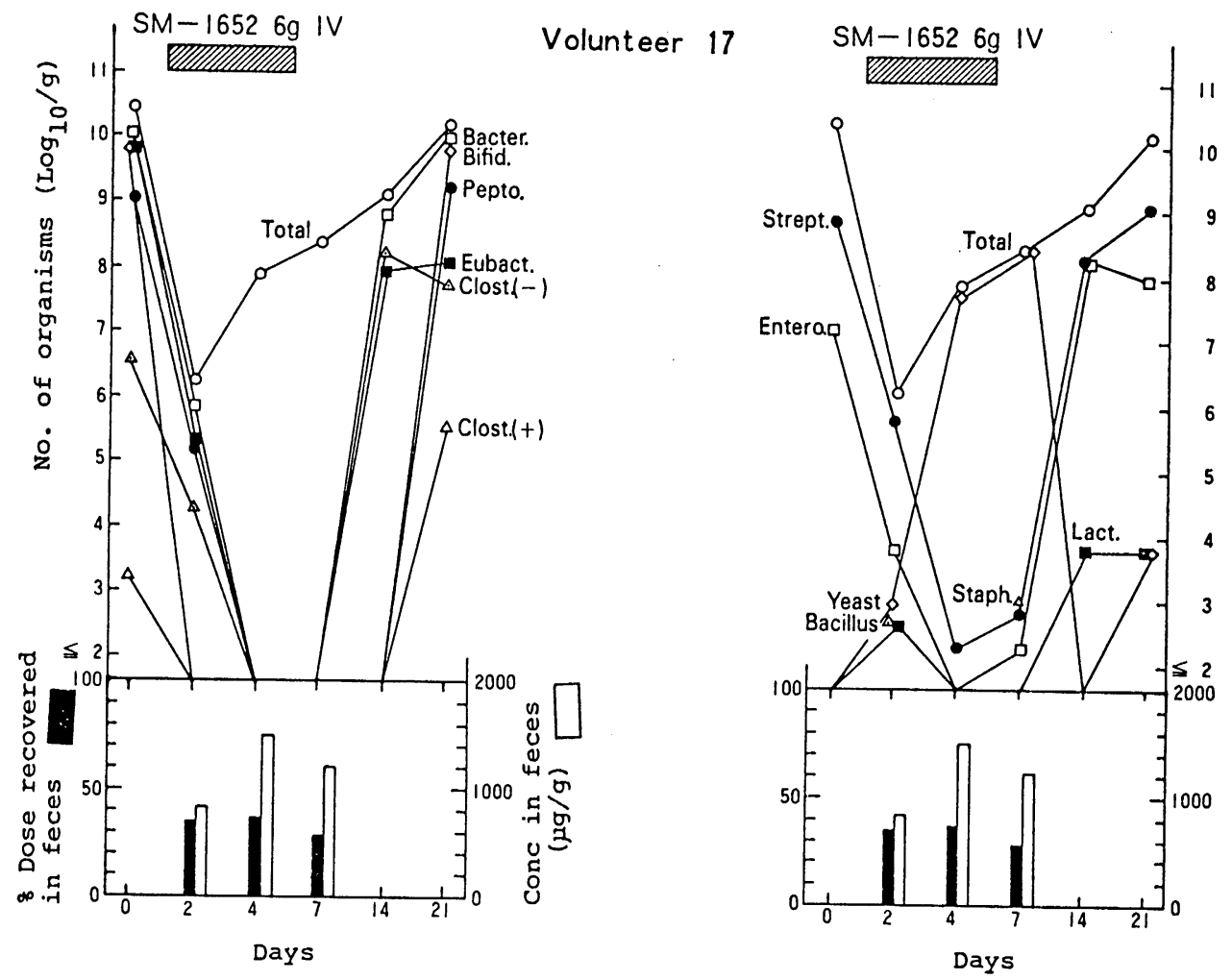

Fig. 4. Effect of SM-1652 on the fecal microflora of volunteer No. 17 and concentrations of the drug in the fecal specimens.

as mentioned previously. All the bacteria in the intestinal flora were strongly suppressed on day 2 of study (one day after the first injection of SM-1652), and then eliminated over the administration period until 1 week after the withdrawal of the drug. It is noteworthy that only yeasts showed overgrowth during the administration period, and accounted for the total counts of flora. Overgrowth of yeasts was also recognized in the other two subjects. The significant difference was the drastic suppression of Streptococci and Enterobacteriaceae in subject No. 17 throughout the administration period compared with the results seen in the beagle dogs treated with CEZ and CFX. It is suggested that such a difference is accounted for by the antibacterial spectrum specific for each drug as well as by the concentration of drug in the intestinal contents. In the lower panels of Fig. 4 are shown the drug concentrations in the stool specimens obtained on days 2, 4, and 7 of study. Approximately $30 \%$ of the drug injected was recovered from stools, which corresponded to an average concentration of $1,200 \mu \mathrm{g}$ of the active form of SM-1652 per $\mathrm{g}$ of stool. It is very likely that the high concentrations of the drug in the intestinal contents strongly affected the becterial composition of stools.

Subject No. 18 showed a quite distinct course of changes in flora as shown in Fig. 5 , and therefore more detailed studies were carried out. The total counts of organisms remained more or less unchanged throughout the experimental period.

Organisms of Bacteroidaceae increased in number on day 4 of study by more than ten times that on day 0 of study, and overgrowth remained throughout the administration period and until 7 days after the 

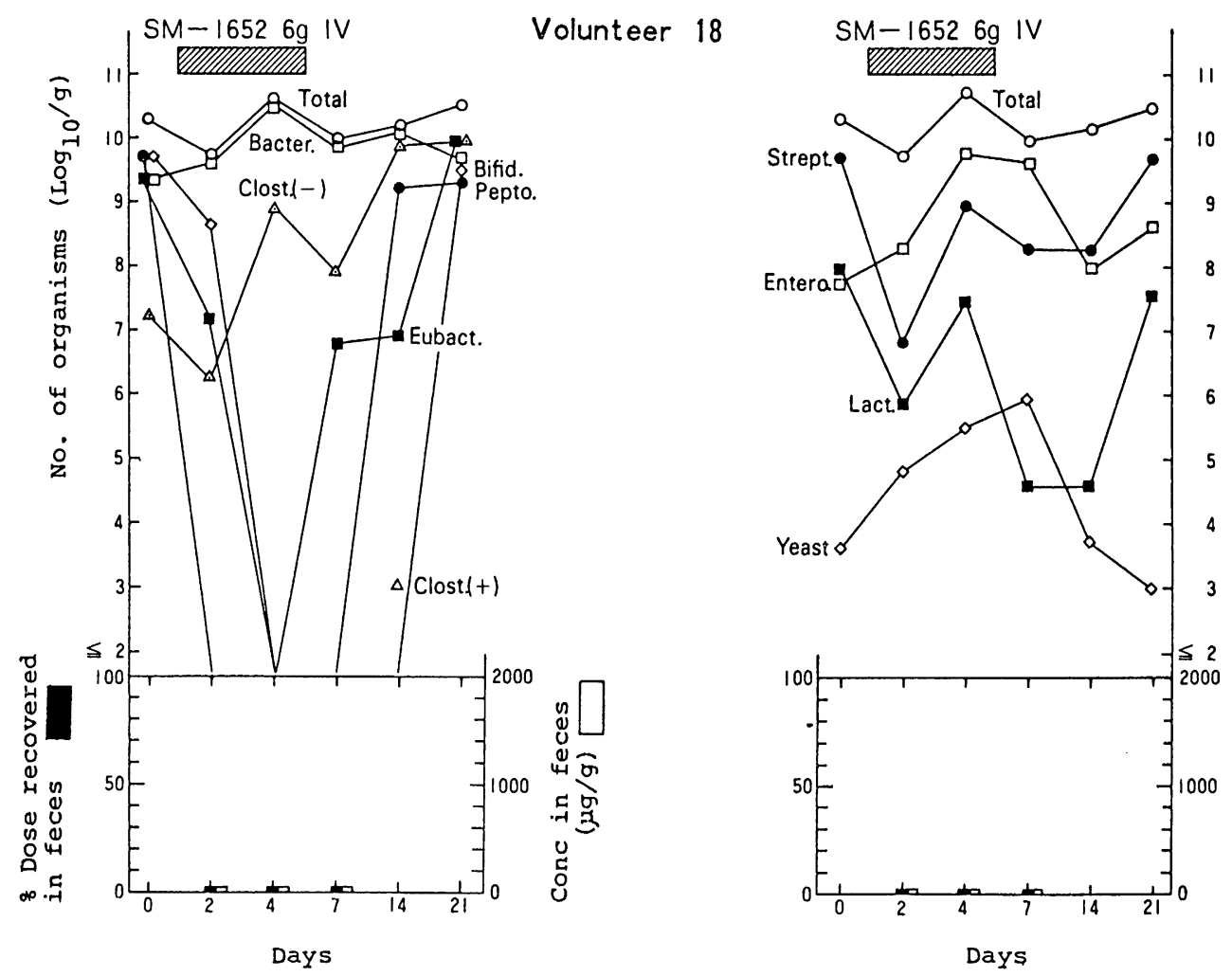

Fig. 5. Effect of SM-1652 on the fecal microflora of volunteer No. 18 and concentrations of the drug in the fecal specimens.

withdrawal of SM-1652. During this period Bacteroidaceae represented the total flora count (the upper left panel of Fig. 5). Other anaerobes were all eliminated except for lecithinase-negative Clostridia which showed an increase in number. Among aerobic bacterial groups, Enterobacteriaceae showed a 100-fold increase on day 4 of study as compared to the figure for pretreatment, though numbers were reduced to normal levels on day 14 of study (the upper right panel of Fig. 5). Streptococci and Lactobacilli were slightly suppressed but not to the extent as in subjects No. 16 and 17. An increase in numbers of approximately $2.5 \mathrm{log}$ cycles was observed for yeasts on day 7 of study.

The SM-1652 concentrations in the stool specimens are shown in the lower panels of Fig. 5, indicating that they were below the detection limit of assay of the active form of the drug $(=2 \mu \mathrm{g} / \mathrm{g})$ on days 2,4 , and 7 of study. The failure in detection of the drug in the fecal samples of subject No. 18 prompted us to search for the presence of any organisms that inactivate the drug among the predominant bacterial groups of the flora. Individual isolates were tested for susceptibility to SM-1652 in vitro. As a result, it was found that the predominant species in the Enterobacteriaceae was Escherichia coli, which was multiply resistant to a variety of antibiotics including SM-1652 and produced $\beta$-lactamase. The strains of $E$. coli isolated on days $0,2,4,7$, and 14 of study showed an identical resistance pattern and harbored a conjugative $\mathrm{R}$ plasmid mediating multiple antibiotic resistance to SM-1652 and other $\beta$-lactam antibiotics, streptomycin and tetracycline. Some strains of Bacteroidaceae tested for resistance were also found to be resistant to SM-1652 and produce $\beta$-lactamase, and were identified as 


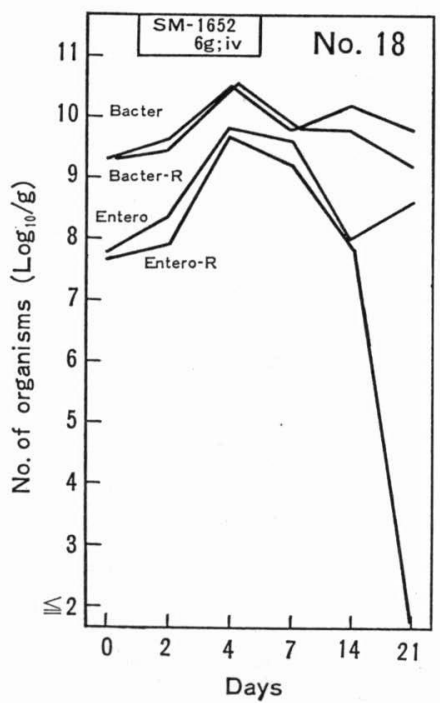

Fig. 6. Presence of SM-1652 resistant organisms of Bacteroidaceae and Enterobacteriaceae in the fecal microflora of volunteer No. 18. Bacter, Bacteroidaceae (total number); Bacter-R, $\beta$-lactamase positive, SM-1652 resistant Bacteroides vulgatus; Entero, Enterobacteriaceae (total number); Entero-R, $\beta$ lactamase positive, SM-1652 resistant Escherichia coli.

Bacteroides vulgatus. Figure 6 shows the presence and proportions of the resistant organisms of $E$. coli and $B$. vulgatus in total Enterobacteriaceae and Bacteroidaceae, respectively. These resistant organisms existed in the flora before drug injection began and increased pronouncedly during the treatment period, becoming the most predominant species among the bacterial groups. However, after the withdrawal of SM-1652, the proportions of resistant organisms tended to decrease. The resistant $E$. coli disappeared on day 21 of study. Failure in detection of the drug in the fecal specimens of subject No. 18 can be accounted for by the drug-inactivating activity of these resistant organisms. The above findings on subject No. 18 are summarized as follows: (i) $\beta$-Lactamase-producing $E$. coli and $B$. vulgatus had been inhabitants of the intestinal microflora of the subject before the administration of SM-1652.

(ii) These resistant organisms almost com- pletely inactivated SM-1652 excreted into the intestinal tract during treatment and showed a selective overgrowth in flora and comprised the most predominant bacterial group during the administration period.

Two groups of cynomolgus monkeys, five in each group, were used to observe the effect of SM-1652 on intestinal flora. One group received intravenous injections of $600 \mathrm{mg}$ per $\mathrm{kg}$ body weight per day for 24 weeks. Stool specimens from these animals were tested for aerobic and anaerobic bacteria at the 12th and 24th week of the administration period. The other group not given the drug served as a control. As shown in Fig. 7, a pronounced suppression of anaerobic flora was recognized in the experimental groups, particularly 12 weeks into the treatment period, as compared to the control group. In contrast, Enterobacteriaceae and yeasts showed a significant increase, while Lactobacilli and Streptococci remained unchanged.

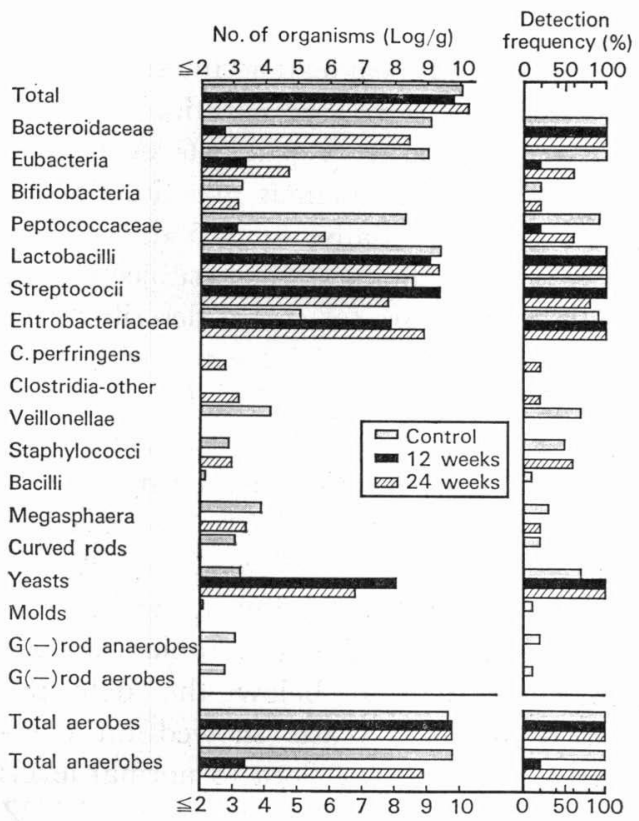

Fig. 7. Effect of SM-1652 on the fecal microflora of cynomolgus monkeys after intravenous injections of $600 \mathrm{mg} / \mathrm{kg} /$ day for 12 and 24 weeks. 


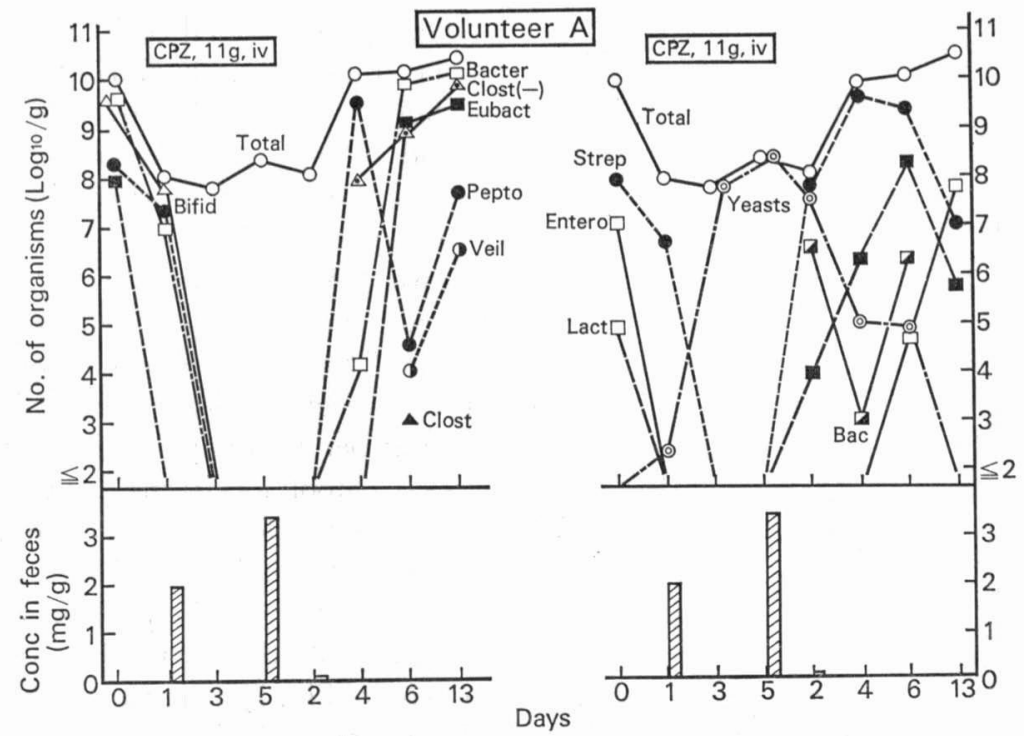

Fig. 8. Effect of cefoperazone on the fecal microflora of volunteer A and concentrations of the drug in the fecal specimens.

Cefoperazone $(C P Z): \mathrm{CPZ}$ is one of the cephalosporin antibiotics that exhibits a potent activity to Pseudomonas aeruginosa and Gram-negative enteric bacteria (3). A study design similar to that of an SM-1652 study was used to reveal the effect of CPZ on human and beagle dog intestinal flora (Manuscripts in preparation). Three adult male volunteers (subjects $\mathrm{A}, \mathrm{B}$, and C) were given intravenous injections of $1 \mathrm{~g}$ of CPZ, 2 times daily, for 5.5 days. The changes in the flora of these subjects were essentially similar to those described for subjects No. 16 and 17 treated with SM1652. Figure 8 depicts the data of subject $\mathrm{A}$ as a representative example. The fecal CPZ concentrations at 1 and 5 days after starting drug administration reached 2 and $3.5 \mathrm{mg}$ per gram of stool, respectively, as presumed by its excretion in the bile (5). The aerobic and the anaerobic bacteria were eliminated to below the detection level, while only yeasts showed an overgrowth. Recovery of flora to normal levels was seen at 13 days after cessation of $\mathrm{CPZ}$ administration.

The effects of CPZ on fecal flora were also investigated in beagle dogs by intra-

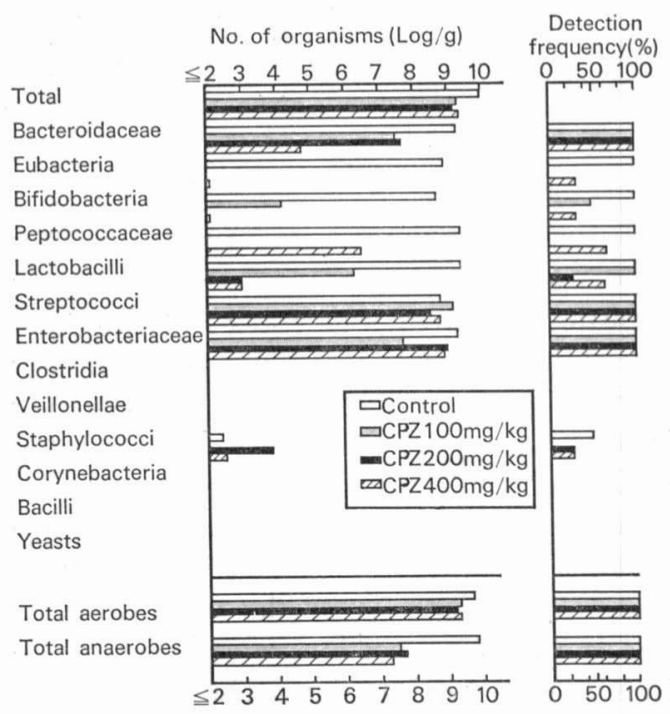

Fig. 9. Effect of cefoperazone on the fecal microflora of beagle dogs after intravenous injections of 100,200 , and $400 \mathrm{mg} / \mathrm{kg} /$ day for 1 month.

venous as well as intramuscular injections. In Fig. 9 are shown the data of experiments on intravenous injection. A total of 10 beagle dogs were assigned to 4 groups, each consisting of 2 or 3 animals: 3 groups were given intravenous injections of 100,200 , and 
$400 \mathrm{mg}$ of $\mathrm{CPZ}$ per $\mathrm{kg}$ body weight per day for 1 month, respectively; the remaining group served as a control. It was evident that anaerobic bacteria and Lactobacilli were suppressed, but Streptococci and Enterobacteriaceae remained unchanged.

\section{Penicillins}

Piperacillin $(P I P C)$ and ampicillin $(A B P C)$. Table 2 shows the effects of PIPC (10) and ABPG on the intestinal microflora of beagle dogs (6). Two groups of animals were treated by intravenous injection of $250 \mathrm{mg}$ and $1 \mathrm{~g}$ of PIPC per $\mathrm{kg}$ body weight per day ( $\mathrm{T}-250 \mathrm{mg} / \mathrm{kg}$ and $\mathrm{T}-1$ $\mathrm{g} / \mathrm{kg}$ groups, respectively) for 1 month, and one group with $1 \mathrm{~g}$ of ABPG (ABPC-1 $\mathrm{g} / \mathrm{kg}$ group) in a similar manner. PIPC strongly suppressed Bifidobacteria, Clostridia, and Streptococci, and slightly, Bacteroidaceae, Peptococcaceae, Lactobacilli, and Streptococci. ABPC showed more or less similar effects to those of PIPG. Susceptibilities of anaerobic bacteria to PIPG, $\mathrm{ABPC}$, and some $\beta$-lactam antibiotics were determined in vitro (Table 3 ) (1). The changes in anaerobic flora seen in the beagle dogs seem to be a reflection of susceptibilities of the organisms in vitro in the intestinal flora.

Rabbits (New Zealand White) were used to test the effects of PIPC and ABPC on the intestinal flora (R. Nakaya, T. Chida, S. Horiuchi, N. Okamura, H. Taniguchi, N. Goto, and K. Fujimoto, Jpn. J. Bacteriol. 33: 262, 1978). The animals (3 in each group) were intravenously injected with 50 and $500 \mathrm{mg}$ of each antibiotic per $\mathrm{kg}$ body weight per day for 15 days. Both drugs significantly suppressed anaerobic flora but not aerobic bacteria. In these experiments, it was observed that the rabbits of the experimental groups lost body weight and died of diarrhea. It is known that penicillins exhibit effects toxic to rabbits and guinea pigs. This was also confirmed in this study.

\section{Pipemidic Acid and DJ-6783}

Pipemidic acid (PPA; Dainippon Pharmaceutical Co., Osaka) and DJ-6783 (sodium 5-ethyl-5, 8-dihydro-8-oxofuro[3, 2-b] [1, 8]naphthyridine-7-carboxylate monoacetate; Daiichi Seiyaku Co., Tokyo) are chemically synthesized, oral antibac-

Table 2. Effects of piperacillin and ampicillin on the intestinal microflora of beagle dogs (6)

\begin{tabular}{|c|c|c|c|c|c|c|c|c|}
\hline \multirow{2}{*}{ Organism } & \multicolumn{2}{|c|}{$\begin{array}{l}\text { Control } \\
\quad(n=2)\end{array}$} & \multicolumn{2}{|c|}{$\begin{array}{c}\mathrm{T}-250 \mathrm{mg} / \mathrm{kg} \\
(n=3)\end{array}$} & \multicolumn{2}{|c|}{$\begin{array}{c}\mathrm{T}-1 \mathrm{~g} / \mathrm{kg} \\
(n=3)\end{array}$} & \multicolumn{2}{|c|}{$\begin{array}{l}\mathrm{ABPC}-1 \mathrm{~g} / \mathrm{kg} \\
(n=3)\end{array}$} \\
\hline & No. ${ }^{a}$ & $\begin{array}{c}\text { Frequency } \\
(\%)\end{array}$ & No. & $\begin{array}{c}\text { Frequency } \\
(\%)\end{array}$ & No. & $\begin{array}{c}\text { Frequency } \\
(\%)\end{array}$ & No. & $\begin{array}{c}\text { Frequency } \\
(\%)\end{array}$ \\
\hline Total & 10.7 & & 10.4 & & 10.2 & & 10.2 & \\
\hline Bacteroidaceae & 10.0 & 100 & 9.3 & 100 & 9.5 & 100 & 9.8 & 100 \\
\hline Spirillaceae & 9.8 & 50 & 9.1 & 33 & 9.2 & 33 & 0 & 0 \\
\hline Eubacteria & 9.9 & 100 & 10.1 & 100 & 9.7 & 100 & 8.7 & 100 \\
\hline Bifidobacteria & 9.7 & 100 & 0 & 0 & 0 & 0 & 8.8 & 67 \\
\hline Peptococcaceae & 9.5 & 100 & 8.8 & 100 & 9.0 & 100 & 9.0 & 100 \\
\hline Lactobacilli & 9.7 & 100 & 9.3 & 100 & 8.4 & 67 & 6.8 & 100 \\
\hline Streptococci & 9.8 & 100 & 8.5 & 100 & 9.1 & 100 & 8.3 & 100 \\
\hline Enterobacteriaceae & 9.3 & 100 & 9.6 & 100 & 9.3 & 100 & 9.7 & 100 \\
\hline Clostridia & 3.5 & 100 & 0 & 0 & 0 & 0 & 0 & 0 \\
\hline Veillonellae & 0 & 0 & 0 & 0 & 0 & 0 & 0 & 0 \\
\hline Staphylococci & 5.7 & 100 & 2.7 & 67 & 3.4 & 100 & 3.8 & 67 \\
\hline Bacilli & 0 & 0 & 0 & 0 & 0 & 0 & 0 & 0 \\
\hline Molds & 0 & 0 & 0 & 0 & 0 & 0 & 0 & 0 \\
\hline Yeasts & 3.0 & 100 & 3.8 & 33 & 4.0 & 33 & 4.3 & 67 \\
\hline
\end{tabular}

$a$ Mean log viable counts per gram of wet stool from the subjects with positive cultures.

$b$ Percentage of dogs from which the bacterial group was detected at the lowest dilution tested. 
Table 3. Susceptibility in vitro of anaerobic organisms against piperacillin and other $\beta$-lactam antibiotics (1)

\begin{tabular}{|c|c|c|c|c|c|c|}
\hline \multirow{2}{*}{ Organism } & \multicolumn{6}{|c|}{$\mathrm{MIC}(\mu \mathrm{g} / \mathrm{ml})$} \\
\hline & PIPC & $\mathrm{ABPC}$ & CBPC & SBPC & CER & CET \\
\hline Bacteroides fragilis NCTC 9343 & 0.78 & 12.5 & 12.5 & 3.13 & 12.5 & 12.5 \\
\hline Bacteroides thetaiotaomicron NCTC 10582 & 25 & 100 & 50 & 12.5 & 100 & 100 \\
\hline Bacteroides vulgatus $\mathrm{E}_{1}$ & 0.39 & 6.25 & 0.39 & $<0.10$ & 6.25 & 6.25 \\
\hline Bacteroides melaninogenicus ssp. intermedius $\mathrm{B} 33008$ & 50 & 0.78 & 6.25 & 6.25 & 0.20 & 0.20 \\
\hline Bacteroides hypermegas $\mathrm{B} 33049$ & 200 & 12.5 & 25 & 100 & 1.56 & 3.13 \\
\hline Fusobacterium necrophorum B33004 & 0.20 & 3.13 & 12.5 & 12.5 & 1.56 & 12.5 \\
\hline Fusobacterium necrophorum VII-34 & 0.39 & 1.56 & $<0.10$ & 1.56 & $<0.10$ & 0.20 \\
\hline Fusodacterium nucleatum B33013 & $<0.10$ & $<0.10$ & 0.20 & $<0.10$ & $<0.10$ & $<0.10$ \\
\hline Fusobacterium varium ATCC 8501 & 200 & 12.5 & 50 & 50 & 1.56 & 3.13 \\
\hline Eubacterium nitritogenes ATCC 25547 & 1.56 & 1.56 & 3.13 & 3.13 & 0.39 & 0.39 \\
\hline Eubacterium limosum ATCC 8486 & $<0.10$ & 0.20 & 25 & 50 & 0.78 & 3.13 \\
\hline Eubacterium rectale VPI 0989 & 0.78 & 3.13 & 12.5 & 100 & 1.56 & 12.5 \\
\hline Propionibacterium avidum B32023 & $<0.10$ & 0.20 & $<0.10$ & $<0.10$ & $<0.10$ & $<0.10$ \\
\hline Propionibacterium acnes B33032 & 400 & 12.5 & 50 & 100 & 1.56 & 3.13 \\
\hline Propionibacterium acnes B33044 & 400 & 12.5 & 50 & 100 & 1.56 & 3.13 \\
\hline Propionibacterium acnes ATCC 49656 & 0.39 & 0.20 & 0.78 & 1.56 & $<0.10$ & $<0.10$ \\
\hline Bifidobacterium pseudolongum $\mathrm{H}-166$ & 0.39 & 0.78 & 3.13 & 6.25 & 3.13 & 6.25 \\
\hline Bifidobacterium longum var. animalis a $\mathrm{H}-165$ & 0.39 & 0.78 & 3.13 & 3.13 & 0.78 & 6.25 \\
\hline Bifidobacterium breve a N4 & 0.39 & 0.39 & 3.13 & 3.13 & 0.78 & 6.25 \\
\hline Bifidobacterium breve b $\mathrm{H}-164$ & 0.78 & 1.56 & 6.25 & 6.25 & 6.25 & 50 \\
\hline Bifidobacterium adobescentis b B33040 & 0.20 & 0.78 & 3.13 & 3.13 & 0.39 & 3.13 \\
\hline Bifidobacterium infantis B33048 & $<0.10$ & 0.78 & 1.56 & 1.56 & 0.78 & 3.13 \\
\hline Lactobacillus ruminis $\mathrm{RF} 1$ & 0.39 & 3.13 & 3.13 & 12.5 & 0.39 & 1.56 \\
\hline Clostridium perfringens $\mathrm{B} 33033$ & $<0.10$ & $<0.10$ & 0.39 & $<0.10$ & 0.78 & 0.20 \\
\hline Peptococcus asaccharolyticus $\mathrm{B} 32030$ & $<0.10$ & $<0.10$ & $<0.10$ & $<0.10$ & $<0.10$ & $<0.10$ \\
\hline Peptococcus asaccharolyticus B33016 & $<0.10$ & 0.78 & 6.25 & 0.20 & $<0.10$ & 0.20 \\
\hline Veillonella alcalescens ATCC 17745 & 50 & 0.78 & 6.25 & 6.25 & 0.20 & 0.20 \\
\hline Megasphaera elsdenii B32043 & $<0.10$ & $<0.10$ & 0.39 & 0.78 & $<0.10$ & $<0.10$ \\
\hline Escherichia coli JC-2 & 6.25 & 12.5 & 100 & 100 & 6.25 & 12.5 \\
\hline Escherichia coli K-12 W677 & 3.13 & 6.25 & 25 & 25 & 3.13 & 3.13 \\
\hline
\end{tabular}

terial drugs related to nalidixic acid. The drugs have an antibacterial activity specific to bacteria belonging to the Enterobacteriaceae group in the intestinal flora. When $20 \mathrm{mg}$ of PPA and DJ-6783 per kg body weight were administered orally twice a day to beagle dogs for 7 days (3 in each group), Enterobacteriaceae organisms were significantly reduced and eliminated, respectively (Figs. 10 and 11) (Manuscripts in preparation). Other changes observed were the decrease of Eubacteria and increase of yeasts in both experimental groups of animals. It is indicated that the effects of these drugs on the flora were well in agreement with their antibacterial spectrum in vitro and were quite distinct from those caused by various $\beta$-lactam antibiotics described above.

\section{Panfuran $S$}

Panfuran S (PFS; dihydroxymethylfuratrizine; Toyama Chemical Co., Tokyo) is a synthetic antibacterial drug which has a broad spectrum. PFS treatment was performed on 11 adult patients with diseases of the urinary tract who were required to be treated with chemotherapeutic agents prior to or after surgical operations. A dose of either 250 or $500 \mathrm{mg}$, 4 times a day, was administered to the subjects for 3 days ( $R$. 


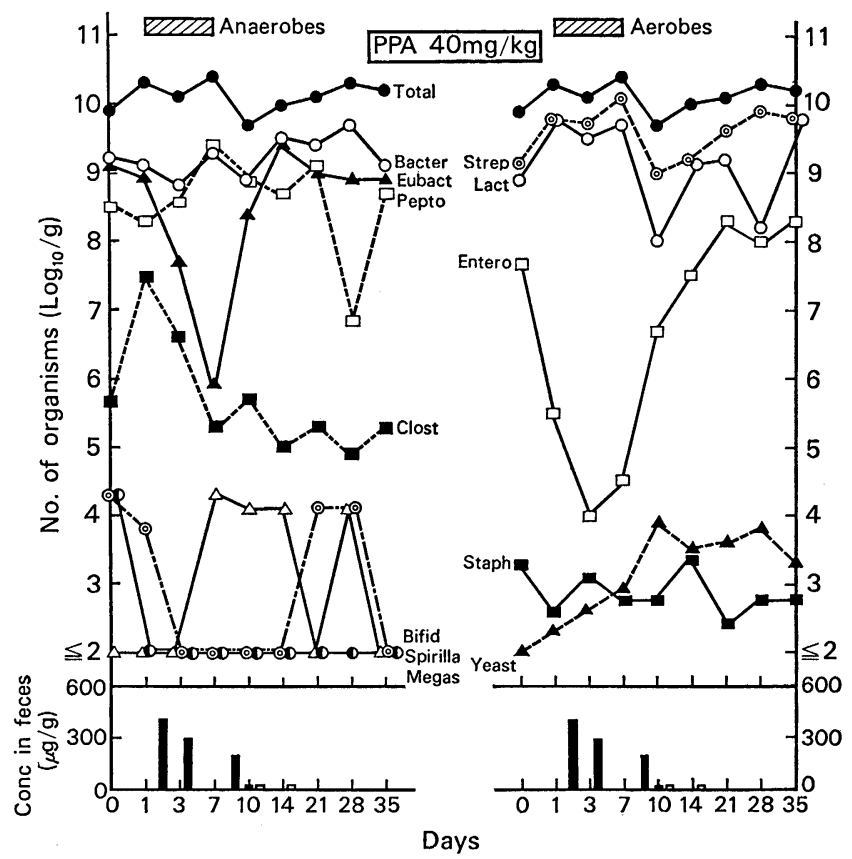

Fig. 10. Effect of pipemidic acid on the fecal microflora of beagle dogs and concentrations of the drug in the fecal specimens. Oral administration of $20 \mathrm{mg} / \mathrm{kg}$, twice a day, for 7 days.

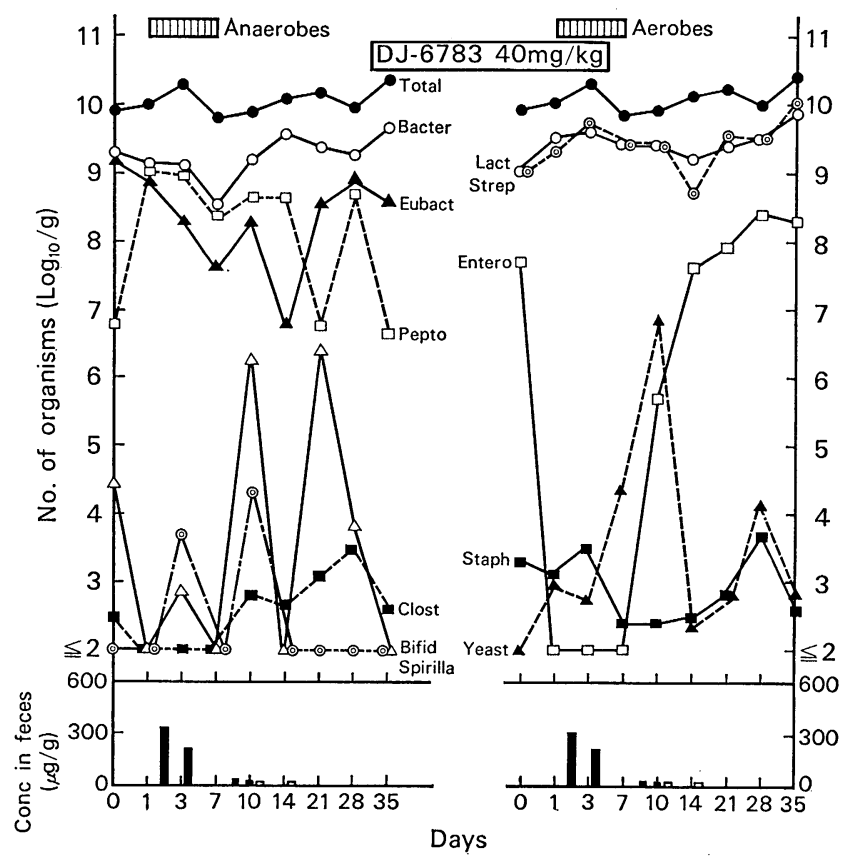

Fig. 11. Effect of DJ-6783 on the fecal microflora of beagle dogs and concentrations of the drug in the fecal specimens. Oral administration of $20 \mathrm{mg} / \mathrm{kg}$, twice a day, for 7 days. 

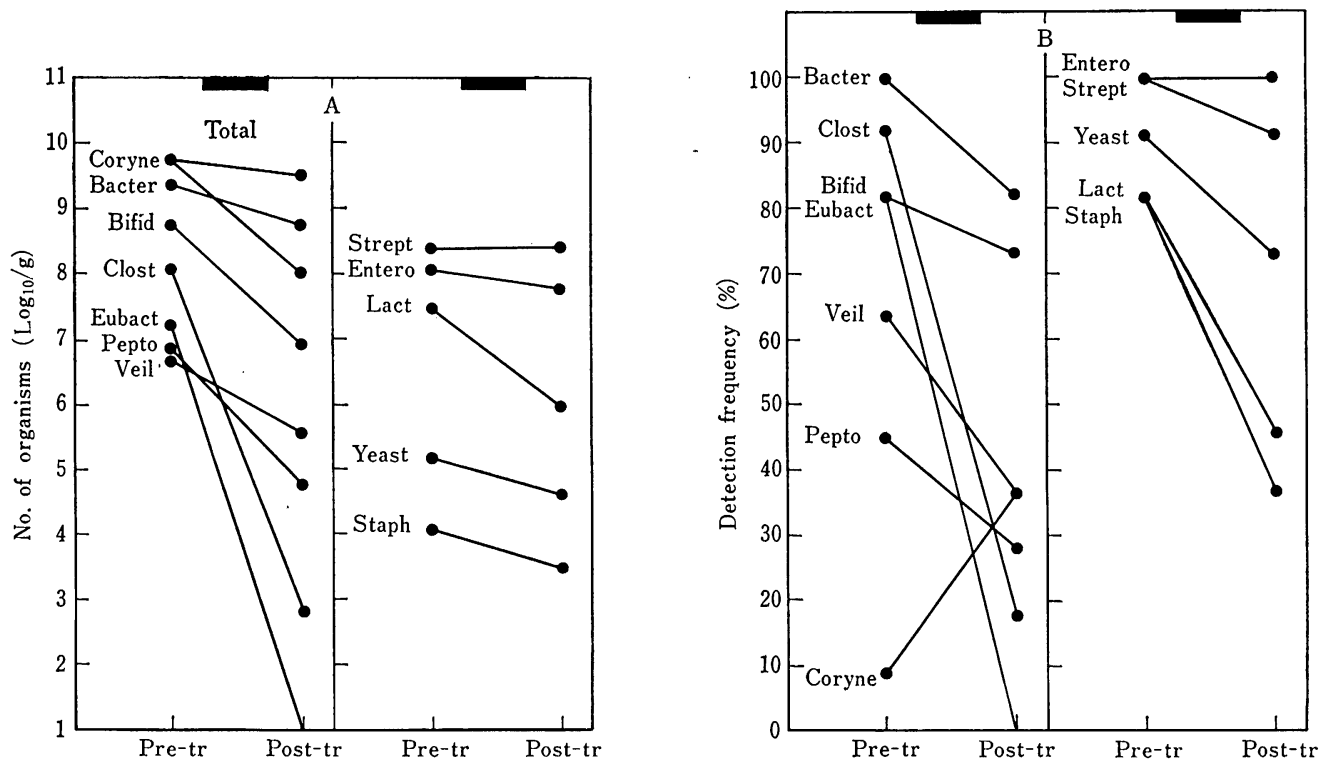

Fig. 12. Effect of Panfuran $\mathrm{S}$ on the fecal microflora of patients. Oral administration of either 250 or $500 \mathrm{mg}, 4$ times a day, for 3 days. Pre-tr, pretreatment; post-tr, posttreatment.

Nakaya, Y. Terawaki, and H. Inugami, Jpn. J. Bacteriol. 30: 113, 1975). As shown in Fig. 12, significant alterations in the intestinal flora were observed after the treatment. Most of the bacterial groups were decreased in number and detection frequency, particularly Clostridia and Eubacteria showing a pronounced decrease. Enterobacteriaceae and Streptococci remained unchanged, while Corynebacteria increased in detection frequency.

\section{Clioquinol}

We have previously reported that patients suffering from subacute myelo-optic neuropathy (SMON) show marked abnormalities in fecal flora, presumably due to the administration of clioquinols (Cli) (7). Cli are synthetic antibacterial drugs that have been widely used for treatment and prophylaxis of mild gastrointestinal disorders, but it is now established that these drugs cause SMON. Table 4 shows the results of our investigations on the fecal flora of SMON patients as compared to those of normal subjects (7), indicating remarkable alterations in the flora of SMON patients.

\section{References}

(1) Chida, T., K. Ishizu, K. Fukuda, and R. Nakaya. 1977. Susceptibility of anaerobic bacteria to a new semisynthetic penicillin T-1220 and related drugs. Igaku-no-Ayumi 101: 889891.

(2) Finegold, S.M. 1977. Anaerobic bacteria in human diseases. Academic Press, New York.

(3) Matsubara, N., S. Minami, T. Muraoka, I. Saikawa, and S. Mitsuhashi. 1979. In vitro antibacterial activity of cefoperazone (T-1551), a new semisynthetic cephalosporin. Antimicrob. Agents Chemother. 16: 731-735.

(4) Mitsuoka, T., K. Ohno, Y. Benno, K. Suzuki, und K. Namba. 1976. Die Faekalflora bei Menschen. IV. Mitteilung: Vergleich des neu entwickelten Verfahrens mit dem bisherigen üblichen Verfahren zur Darmfloraanalyse. Zbl. Bakt. Hyg., I. Abt. Orig. A 234: 219-233.

(5) Nakamura, T., I. Hashimoto, Y. Sawada, J. Mikami, E. Bekki, S. Hirasawa, H. Abe, and Y. Watanabe. 1980. Cefoperazone concentration in bile and gall bladder wall after intravenous administration. Antimicrob. Agents Chemother. 18: 980-982.

(6) Nakaya, R., T. Chida, K. Ishizu, and H. Taniguchi. 1977. Effects of a new semisynthetic 
Table 4. Fecal flora in normal subjects and SMON patients ${ }^{a}$ (7)

\begin{tabular}{|c|c|c|c|c|}
\hline \multirow[b]{2}{*}{ Bacterial group } & \multirow[b]{2}{*}{$\begin{array}{l}\text { Normal } \\
\text { subjects } \\
\text { (35 cases) }\end{array}$} & \multicolumn{3}{|c|}{ SMON patients } \\
\hline & & $\begin{array}{c}\text { Total } \\
(51 \text { cases })\end{array}$ & $\begin{array}{l}\text { Non-clio- } \\
\text { quinol }{ }^{b} \\
(35 \text { cases) }\end{array}$ & $\begin{array}{l}\text { Clio- } \\
\text { quinol } b \\
\text { (16 cases) }\end{array}$ \\
\hline Total counts & $10.7 \pm 0.4$ & $10.1 \pm 0.7 * *$ & $10.1 \pm 0.6$ & $10.1 \pm 1.0$ \\
\hline Bacteroidaceae & $\begin{array}{c}10.2 \pm 0.6 \\
(97)\end{array}$ & $\begin{array}{c}9.2 \pm 1.2 * * \\
(96)\end{array}$ & $\begin{array}{c}9.3 \pm 1.2 \\
(100)\end{array}$ & $\begin{array}{c}9.0 \pm 1.2 \\
(88)\end{array}$ \\
\hline Eubacteria & $\begin{array}{c}9.7 \pm 0.7 \\
(91)\end{array}$ & $\begin{array}{c}8.7 \pm 1.4^{* *} \\
(75)^{*}\end{array}$ & $\begin{array}{c}8.8 \pm 1.2 \\
(83)\end{array}$ & $\begin{array}{c}8.4 \pm 1.9 \\
(56) \#\end{array}$ \\
\hline Bifidobacteria & $\begin{array}{c}9.9 \pm 0.6 \\
(94)\end{array}$ & $\frac{8.8 \pm 1.1 * *}{(82)}$ & $\begin{array}{c}8.7 \pm 1.2 \\
(89)\end{array}$ & $\begin{array}{c}9.0 \pm 1.2 \\
(69)\end{array}$ \\
\hline Peptostreptococci & $\begin{array}{c}8.6 \pm 2.0 \\
(34)\end{array}$ & $\begin{array}{c}8.3 \pm 1.0 \\
(33)\end{array}$ & $\begin{array}{c}8.3 \pm 1.2 \\
(31)\end{array}$ & $\begin{array}{l}8.3 \pm 0.9 \\
(38)\end{array}$ \\
\hline Lactobacilli & $\begin{array}{c}7.4 \pm 1.8 \\
(100)\end{array}$ & $\frac{6.5 \pm 1.7 *}{(79)}$ & $\begin{array}{c}6.4 \pm 1.7 \\
(80)\end{array}$ & $\begin{array}{c}6.8 \pm 1.8 \\
(75)\end{array}$ \\
\hline Streptococci & $\begin{array}{c}8.2 \pm 1.5 \\
(100)\end{array}$ & $\begin{array}{c}8.7 \pm 1.4 \\
(100)\end{array}$ & $\begin{array}{c}8.5 \pm 1.5 \\
(100)\end{array}$ & $\begin{array}{c}9.1 \pm 1.1 \\
(100)\end{array}$ \\
\hline Enterobacteriaceae & $\begin{array}{c}8.2 \pm 1.3 \\
(100)\end{array}$ & $\begin{array}{c}8.4 \pm 1.3 \\
(100)\end{array}$ & $\begin{array}{c}8.3 \pm 1.3 \\
(100)\end{array}$ & $\begin{array}{c}8.6 \pm 1.3 \\
(100)\end{array}$ \\
\hline Clostridia & $\begin{array}{c}6.1 \pm 1.5 \\
(69)\end{array}$ & $\begin{array}{c}5.9 \pm 2.2 \\
(49)\end{array}$ & $\begin{array}{c}5.8 \pm 2.3 \\
(63)\end{array}$ & $\begin{array}{c}7.0 \pm 0.8 \\
(19) \#\end{array}$ \\
\hline Veillonellae & $\begin{array}{c}4.5 \pm 1.7 \\
(69)\end{array}$ & $\frac{6.9 \pm 2.0 * *}{(63)}$ & $\begin{array}{c}6.9 \pm 2.1 \\
(63)\end{array}$ & $\begin{array}{c}6.9 \pm 1.9 \\
(63)\end{array}$ \\
\hline Staphylococci & $\begin{array}{c}3.9 \pm 1.2 \\
(94)\end{array}$ & $\begin{array}{c}5.2 \pm 2.1^{* *} \\
(61)^{*}\end{array}$ & $\begin{array}{c}5.1 \pm 2.1 \\
(63)\end{array}$ & $\begin{array}{c}5.9 \pm 2.2 \\
(56)\end{array}$ \\
\hline Bacilli & $3.1 \pm 0.6$ & $\begin{array}{c}6.4 \pm 1.9 \\
(20)\end{array}$ & $\begin{array}{c}6.5 \pm 1.7 \\
(20)\end{array}$ & $\begin{array}{c}6.4 \pm 2.8 \\
(19)\end{array}$ \\
\hline Molds & $\begin{array}{c}2.5 \pm 0.3 \\
(14)\end{array}$ & $\begin{array}{l}3.2 \\
(2) *\end{array}$ & $\begin{array}{c}3.2 \\
(3)\end{array}$ & $\begin{array}{l}0 \\
(0)\end{array}$ \\
\hline Yeasts & $\begin{array}{c}3.7 \pm 1.3 \\
(74)\end{array}$ & $\begin{array}{c}4.2 \pm 1.5 \\
(59)\end{array}$ & $\begin{array}{c}4.5 \pm 1.5 \\
(60)\end{array}$ & $\begin{array}{c}3.6 \pm 1.3 \\
(56)\end{array}$ \\
\hline
\end{tabular}

$a$ Values are expressed as $\log _{10}$ of average counts \pm confidence limit per gram of wet stool at $p=0.05$ of those subjects with positive cultures. Values in parentheses are percentages of subjects from whom the bacterial groups were detected at the lowest dilution tested.

${ }^{b}$ Non-clioquinol group had not received clioquinol at least within 7 days before the stool culture was performed, while clioquinol group had.

* Difference is statistically significant at $p<0.05$ between normal subjects and SMON patients.

** Difference is statistically significant at $p<0.01$ between normal subjects and SMON patients.

\# Difference is statistically significant at $p<0.05$ between clioquinol and nonclioquinol groups.

penicillin $\mathrm{T}-1220$ on the intestinal microflora in dogs. Igaku-no-Ayumi 101: 773-775.

(7) Nakaya, R., H. Inugami, T. Mitsuoka, and A. Igata. 1976. Abnormalities in the fecal flora of subacute myelo-optic neuropathy (SMON) patients and effects of clioquinols on human intestinal flora, p. 315-320. In J.D. Williams, and A.M. Geddes (ed.) Chemotherapy, Vol. 4. Plenum Publishing Corporation, New York.

(8) Nanri, S. 1980. Relationship between the intestinal flora and the urinary tract infection. J. Japan. Assoc. Infect. Dis. 54: 780-787.
(9) Sutter, U.L., and S.M. Finegold. 1974. The effect of antimicrobial agents on human faecal flora: studies with cephalexin, cyclacillin and clindamycin, p. 229-240. In F.A. Skinner, and J.C. Carr (ed.), The normal microbial flora of man. Academic Press, Inc., London.

(10) Ueo, K., Y. Fukuoka, T. Hayashi, T. Yasuda, H. Taki, M. Tai, Y. Watanabe, I. Saikawa, and S. Mitsuhashi. 1977. In vitro and in vivo antibacterial activity of T-1220, a new semisynthetic penicillin. Antimicrob. Agents Chemother. 12: 455-460. 